\title{
Chapter 12 \\ Multiple Roles and Role Conflict: Seafarers As Economic, Humanitarian and Security Actors
}

\author{
Amaha Senu
}

\section{Introduction}

Undocumented migrants at sea and maritime stowaways in ports impinge upon the world of the seafarer in ways that are often challenging. ${ }^{1}$ According to the International Chamber of Shipping (ICS 2018), merchant ships rescued around 100,000 migrants in the Mediterranean in the period between 2015 and 2018 (ICS 2018). The operations, involving migrants at sea, pose significant challenges to seafarers in terms of scale, safety and security and differ from conventional rescue operations such as the rescue of crew members from an abandoned ship (ICS 2015, p. 2). While seafarers are, as far as practicable, bound by law to render assistance and come to the rescue of anyone at sea under the UNCLOS, SOLAS, SAR and SALVAGE Conventions, ${ }^{2}$ the provisions in these legal instruments do not take account of the challenges which such large scale rescue operations entail. Seafarers are neither adequately trained nor resourced to undertake such activities although they are legally obligated to do so (ICS 2015; Kilpatrick and Smith 2015; Kilpatrick 2017).

This chapter is partly based on an earlier version presented at the Department for Politics and International Relations Postgraduate Research Conference at Cardiff University, UK, on the 7th of May 2014. I am grateful to Professor Christian Bueger, Jan Stockbruegger and the editors of this volume for their constructive comments.

\footnotetext{
${ }^{1}$ Seafarers are construed broadly in this chapter to encompass those working on fishing vessels although the discussion largely revolves around those working on merchant cargo ships.

${ }^{2}$ United Nations Convention on the Law of the Sea (UNCLOS) 1982; International Convention for the Safety of Life at Sea (SOLAS) 1974; International Convention on Maritime Search and Rescue (SAR) 1979; International Convention on Salvage (SALVAGE) 1989.
}

\footnotetext{
A. Senu $(\bowtie)$

Johannesburg Institute for Advanced Study, University of Johannesburg, Johannesburg, South Africa
} 
The shipping industry as a whole, in conjunction with relevant institutions such as the International Maritime Organization (IMO) and the United Nations High Commissioner for Refugees (UNHCR), has been proactive in attempting to provide guidance for seafarers to help them cope with the challenges they face when encountering migrants at sea (ICS 2015; IMO et al. 2015; Kellett et al. 2015). While various industry publications, and to a lesser extent reports in the media, have emphasised the challenges and problems seafarers contend with when encountering undocumented migrants, the academic literature has largely avoided substantive engagement with the implications of undocumented migration for seafarers. Although there are notable exceptions that specifically focus on shipping and, to a limited extent, on seafarers (Maccanico 2012; Maquet and Zortea 2013; Basaran 2014, 2015; Aarstad 2015; Goddard 2015; Kilpatrick and Smith 2015; Kilpatrick 2017), the lived experiences of seafarers are not given a central place in the academic literature on migration governance, border control, and humanitarianism at sea. Instead the emphasis tends to be on analyses of the provisions in various legal instruments as opposed to a focus on and an analysis of the experiences of seafarers in their interactions with migrants at sea (Ort 1991; Tauman 2002; Bailliet 2003; Davies 2003; Coppens and Somers 2010; Coppens 2013b). The literature relating to the encounters of seafarers with stowaways, a group which also carry significant implications for shipping, similarly demonstrates a scarcity of data relating to their experiences (Mason 1987; Jarvis 1988; Ort 1991; Nourse 1993; McConnell 1997; Steglich 1999).

This chapter aims to situate seafarers at the centre of the discussion of undocumented migration. As such, it explores the tensions, contradictions and outcomes that arise from the often-diverging expectations placed upon them. I attempt to demonstrate how seafarers are forced to assume multiple and conflicting roles, i.e. economic, humanitarian and security roles, in their interactions with migrants in the maritime sphere. The academic literature, documents from relevant institutions and publicly available sources on migration across the Mediterranean, as well as data from my own research on maritime stowaways, are drawn upon here to make the argument that serious implications for both seafarers and migrants emerge when seafarers find themselves compelled to navigate these conflicting roles.

\section{Rescuing Migrants in the Mediterranean Sea}

Rescuing migrants at sea is a significantly more challenging task for seafarers than the rescue operations merchant ships routinely engage in. Cases such as that of $M V$ King Jacob where close to 800 migrants perished when a migrant boat collided into the ship attempting to render assistance (Miglierini 2016; https://deathbyrescue.org/ report/narrative/), highlight the hazardous nature of large-scale rescue operations. Nevertheless, as previously stated, the provisions in the legal texts establishing the foundations of humanitarianism at sea oblige seafarers to engage in such large-scale rescue operations involving migrants. 
Captain Jamie Wilson, who was involved in the rescue of 907 migrants off the coast of Libya in January 2017, indicated that although his crew were prepared for the possibility of encountering migrants, albeit without any previous rescue experience, they were overwhelmed by the sheer numbers (BBC 2017). His account affirms that humanitarianism at sea usually takes precedence over any other considerations for many seafarers.

As captain, you're bound by law to proceed to help anyone in danger, [...] There's no grey area for me as captain - you have to go and assist. My duty is to save lives at sea. (BBC 2017)

However, there is also a level of anxiousness on the part of seafarers when they encounter migrants at sea. Migrants are often found in large numbers, and there are concerns that they may pose health and safety risks to seafarers. On 22 October 2014, the dry bulk carrier MV CS Caprice was alerted by Malta's Rescue Coordination Centre to proceed to the assistance of a boat in distress carrying migrants. Whereas the ship had only 20 crew members on board, the migrants they eventually rescued numbered 510 individuals. Captain Rajesh Dhadwal, who was the designated person ashore (DPA) providing guidance to the crew at the time, indicated that the crew had reservations and concerns. His account highlights the health, safety and security concerns that are often felt by seafarers in such situations together with the desire to uphold their humanitarian obligations.

The human spirit has to lift itself to another level. You cannot attempt this scale of operation if you are thinking about compensation or 'what if the migrants have Ebola?' or 'what if there are terrorists among them and they take over the ship?' You have to put aside the 'what ifs'. [... Isis has said it might use this as a channel to export terrorism, this is a real threat and it becomes so real when you start talking about gas tankers where, if people took over the ship, you would be facing an environmental disaster. [...] When you are in the middle of the sea, with so many people with no papers, how can you stand off and not help them, thinking of all the various scenarios? If they die and they were not criminal or terrorists, then who is liable for their deaths? (Fairplay 2015).

Considering the rescue operation took place at the time of the Ebola epidemic in West Africa and the political crises in Libya and Syria, his account highlights the profound health and security concerns seafarers could have when engaged in rescuing migrants in the Mediterranean Sea and beyond. Indeed, what Valverde (2014, p. 384) calls 'the affective dimensions of security' are ever present on board in these situations whereby seafarers' concerns can be influenced by the discursive climate where criminality and terrorism are often invoked alongside issues of migration (Huysmans 2000, 2006). Furthermore, there have been cases in which migrants became uncooperative, demanding to be taken to specific destinations, and leaving seafarers with no alternative but to acquiesce to their demands. The case of MV Tampa is one example in which 440 rescued migrants threatened to commit suicide and undertake hunger strikes unless they were taken to Australia, which prevented the captain from proceeding to his intended next port of call, Singapore (Tauman 2002; Bailliet 2003; Kenney Jr and Tasikas 2003). A more recent example is the case of the cruise liner Salamis Filoxenia which rescued about 300 migrants who subsequently refused to disembark in Cyprus, demanding to be taken to Italy 
instead. The standoff was reported to have cost the company 'hundreds of thousands of euros' (BBC 2014). This should also be considered in the context of the longer period of time that migrants can sometimes remain on board.

In the case of the MV CS Caprice, the crew cared for the migrants on board for 4 days because weather conditions necessitated their disembarking at a different port from that initially planned. Interestingly, the DPA pointed out that the charterers had refused to pay for the 4 days that they considered the ship was 'off-hire', highlighting the charter-party issues which ship owners may be faced with (Fairplay 2015). The cost to owners is further exacerbated when there is lack of clarity as to where the migrants should be taken. For instance, there has been a long dispute between Italy and Malta concerning the responsibility for allowing disembarkation onto their respective territories (see Coppens 2013a, b for a detailed discussion on this). The lack of clarity on the disembarkation of migrants was also highlighted by the DPA in the case of MV CS Caprice.

When we picked up that group of 510 people, we did not know where we would be able to take them; we did not know how long they would be with us. [...]We need clear guidelines explaining: in the Mediterranean Sea, within these boundaries, migrants should be taken to so and so place, or reported to so and so. (Fairplay 2015)

A case involving a Maltese fishing boat Budafel in 2007 with a crew of four, brings forth the tension that arises from the diverging humanitarian, security and economic considerations more clearly. Twenty-seven migrants were forced to hold on to the tuna pen for what was initially reported as $24 \mathrm{~h}$ when the crew refused to allow the migrants to board their vessel while the Maltese and Libyan authorities argued about which country should assume the responsibility of taking them. The owner explicitly indicated security concerns as the rationale behind the fisher's decision in prohibiting the migrants from boarding. His account highlights the tension between the commitment to humanitarian assistance and the security concerns of the sailors on board.

"As a Maltese, I'm prepared to assist people, but there's a limit to everything. What if these 24 strong men rebelled and tried to assume control of the boat?" he asked, admitting that the immigrants' lives were at stake. (Grech 2007).

Interviews by the Italian Council for Refugees (CIR) with the survivors after they were rescued by the Italian navy, however, revealed that the migrants actually clung to the buoys around the tuna pen for 3 days. The four crew members of the Budafel provided the migrants with some fruit and water while stopping short of allowing the migrants to board the vessel (CIR 2007, p. 3). Basaran (2015, p. 213) refers to such practices as 'humanitarianism light' inasmuch as they involve 'providing directions, water, and possibly food to people in distress, but without taking them on board, hence avoiding complications associated with rescue.' What is interesting here is while Malta and Libya wrangled back and forth arguing which country should assume responsibility, the Maltese Justice and Home Affairs Minister informed reporters that the Maltese authorities had emphasised to the Captain of the Budafel that he was obligated to take the migrants on board if they were in any danger (CIR 2007, p. 3). 
This clearly underscores the tension between the humanitarian roles expected of seafarers and the contradictory considerations that stem from security considerations in which seafarers are simultaneously concerned about their own safety as well as the difficulty of obtaining the consent of states to disembark the migrants. Furthermore, it was also reported in the above case that the captain had argued 'he could not take the persons to Malta as he could not risk losing the $€ 1$ million-worth catch of tuna being hauled by the ship, which was heading to Spain' (CIR 2007, p. 3), drawing our attention to the economic considerations that come into play when seafarers rescue migrants at sea.

In addition to the operational challenges of rescuing migrants, the anxieties and fears felt by seafarers and the associated economic cost of rendering assistance, the margins of humanitarianism at sea have been shrunk by states' border security regimes. The long-standing legal duty to render assistance at sea has been gradually eroded through increasing laws and practices at the national, regional and supranational levels effectively discouraging rescue at sea that is not sanctioned by states. As Cuttitta (2014, p. 33) and Basaran (2014, p. 367) note, non-state actors are discouraged from independent rescue and assistance through the introduction of legislation that gradually chips away the protection humanitarian acts are afforded from criminalisation. This trend is also noted by Fekete (2009) and Williams (2016) who point out that activists, sympathetic politicians, medical professionals and ordinary citizens have all been prosecuted for acting in accordance with humanitarian ideals in relation to undocumented migrants in different countries.

In the case of Mediterranean migration, this is done through 'anti-smuggling legislation' that can criminalise independent rescue efforts (Basaran 2014). The cases of MV Cap Anamur, MV Fakhreddine Morthada and MV Mohamed el-Hedi are some of the well-known examples of seafarers being prosecuted for rescuing migrants at sea and taking them to a place of safety (Statewatch 2007; Basaran 2014).

MV Cap Anamur, eponymously named after the non-governmental organization (NGO) it belonged to, was involved in rescuing migrants in the Mediterranean, and in June 2004 the vessel rescued 37 migrants in the area between Libya and the Italian island of Lampedusa. The president of the German NGO Cap Anamur, the captain and the first [sic] officer were arrested and faced charges of helping the migrants to enter Italy illegally. This took place after the ship stayed over 2 weeks at sea awaiting permission to enter, 'amid a shortage of supplies, threats from the migrants that they would jump into the sea, and worsening physical and psychological conditions experienced by both migrants and crew members' (Statewatch 2007). While the accused were finally acquitted (BBC 2009), the charging of the personnel in the first place led the NGO to terminate its rescue activities in 2004 (Cusumano 2017, p. 92).

Similarly, the crew of the Tunisian fishing boats Fakhreddine Morthada and Mohamed el-Hedi rescued 44 migrants in August 2007 and proceeded to Lampedusa disregarding non-disembarkation orders by the Italian authorities. They were promptly arrested and tried on charges of smuggling which were subsequently dropped. However, the captains of each vessel were convicted of 'charges of 
resisting public officer and committing violence against a warship', and sentenced to two and half years imprisonment as well as a fine of $€ 444,000$ each, which were subsequently dropped following appeal (Basaran 2014, p. 376). Although all the seafarers were ultimately exonerated, the trials lasted many years, the fishing vessels were confiscated for long periods and rendered unusable, 'effectively amounting to the loss of [the fishers'] economic livelihoods' (Basaran 2014, p. 376). Although all the above cases led to eventual acquittals, Basaran (2014, p. 377) emphasises that the prosecution process and the cost of the criminal procedure were effectively used as a deterrent to humanitarian acts unsanctioned by the state.

It is worth reconsidering the implications of such developments for seafarers and migrants alike. There are certainly precedents in which fishing and cargo vessels have been refused entry into port after having rescued migrants. One case involved a Spanish fishing vessel Francisco Y Catalina that rescued 51 migrants on 15th July 2006 and was denied permission to land in Malta. The ship was forced to anchor six miles from the coast for 6 days under extreme overcrowding, with some of the migrants falling ill (Maccanico 2006). Similarly, on 30th January 2007 MV Marina I sent a distress call to the Spanish Coastguard after rescuing over 300 undocumented migrants. Nevertheless, it took 2 weeks for the various nations involved (Spain, Senegal and Mauritania) to come to an agreement and disembarkation to take place (Coppens and Somers 2010; Coppens 2013b). A third example is that of the Turkish vessel Pinar E that rescued 140 migrants in April 2009 and the high-profile dispute that ensued for 4 days between Malta and Italy regarding who would be responsible for the migrants (HRW 2009; The Telegraph 2009). There is also the case of the oil tanker MT Salamis which rescued 102 migrants on 5th August 2013 and the 2 days standoff that followed between the vessel and Maltese authorities due to disagreement over disembarkation (MaltaToday 2013; WatchTheMed 2013).

When such disembarkation refusals and delays combine with the threat of sanction and prosecution, the economic cost of rescue, seafarers' fears and anxieties and the significant challenge of providing humanitarian assistance to large numbers of migrants while having only a handful of crew on board, some seafarers might deem 'looking the other way' to be an easier option. There are a number of testimonies from migrants that suggest that some ships simply pass by without rendering assistance at sea (CIR 2007; HRW 2009; Strik 2012; Heller and Pezzani 2016). Such actions self-evidently put the migrants' lives at risk. Furthermore, seafarers who are guilty of such actions may, nevertheless, suffer from the psychological consequences of their failure to stop and assist fellow humans in distress.

\section{Stowaways}

Maritime stowaways have a pedigree as old as shipping itself, and some of the challenges they pose to shipping are not new. However, contemporary stowaways produce significant tensions for seafarers in terms of their economic, security and humanitarian obligations. When the vessel is in port, seafarers are preoccupied with 
associated security and economic roles whereas humanitarian roles are introduced when stowaways are detected on board while the vessel is at sea.

Stowaways have always entailed an economic cost to ship owners and, hence, a number of procedures have long been prescribed to seafarers to prevent stowaways from boarding and to detect them before a ship departs from port. Some of the recommended practices include: controlling access to the ship from both shore and sea while the ship is berthed and at anchor; implementing an identification pass system at the ship's gangway; roving patrols and the maintenance of a security watch; sealing off restricted areas on board; adequate lighting at night; a systematic stowaway search assisted by a checklist prior to departure; making use of technologies such as CCTV cameras, $\mathrm{CO}_{2}$ and heat detectors, automatic intrusion detection devices (AID) and alarm systems to detect stowaways (Parrit and Parker 1992; Holder 1997; Robertson 1997; NEPIA 2001; Miller 2009; BIMCO 2013; Jones 2014; GARD n.d.). While these procedures were recommended as early as the 1990s, the introduction of the International Ship and Port Facility Security Code (ISPS) following the 9-11 terrorist attacks formalised these procedures and rendered them mandatory, making the presence of stowaways on board a breach in a ship's security plan implementation. Thus, prevention of boarding by unauthorised personnel, including stowaways, is now part of the explicit security roles seafarers are obliged to assume in ports. However, seafarers also have primary economic and operational obligations to their employers, such as cargo work, liaising with various parties, bunkering, maintenance and so on. Reconciling the above security and commercial expectations can often be challenging for seafarers, particularly when their security measures are not complemented by an effective port security infrastructure, as the following account from one captain highlights.

From the ship's side, we were left to do all the work with no extra help for the crew. My company said right from the start when we first started setting up ISPS code, a lot of the captains wrote to say, 'okay, we need one extra seaman on deck.' 'No way. No, you're not getting any extra man.' So, we had to do it all ourselves. But what we saw from our side, we're going through all this huge, massive procedures, setting up procedures on board, and audits and inspections and security measures, and the ports are doing nothing. We go to some ports and there's thousands of people just wandering around the jetty. And we're the ones who have to try and stop them getting on board. But nobody was taking the trouble to try and stop them getting into the ports. [...]So, a lot of things didn't get done in port that we'd like to have done. All the maintenance, painting and cleaning. There's the whole crew that's just occupied in manning the gangway and walking up and down the ship's side, you know, looking over the side, canoes, boats. It was a huge burden on the ships. (Capt. Smith, British)

Nonetheless, the security measures taken by seafarers do not always prevent stowaways from boarding ships. My research on stowaways indicates their creative adaptability to measures put in place to deter their movement. This strongly resonates with observations made about the creative agencies of other groups of undocumented migrants on the move (Papadopoulos and Tsianos 2013; Andersson 2014). Furthermore, interviews with stowaways and security experts also revealed that stowaways are, at times, able to avoid detection even when thorough searches are conducted with professional experts assisted by sniffer dogs. 
The reaction of seafarers can be quite strong when they discover stowaways at sea. This is due to a number factors that include: frustration over breaches in both ship and port security arrangements; awareness of the significant cost stowaways entail to ship owners and their protection and indemnity (P \& I) club insurers; the added workload that comes with caring for and monitoring stowaways on board as well as the pervasive concerns about implications for seafarers' jobs and careers. In addition, the affective dimensions of security alluded to earlier are prominent, particularly in the initial interactions between seafarers and stowaways during which time both groups are fearful and apprehensive. For seafarers, this is due to the link made, in the industry discourse, between piracy, terrorism, criminality and stowaways. In addition, there have been incidents in which a small number of stowaways became violent and effectively hijacked the ship, reinforcing the security concerns of having stowaways on board (BBC 2000; Cooper 2014; Scully 2017). For the stowaways, their concerns are about the potentially violent reactions by seafarers, perceptions that are based on shared past experiences. Such apprehension during the initial encounter at times manifests itself in seafarers carrying 'protective tools'.

Third officer and duty $\mathrm{AB}$ were scared because the incident happened at night time. [...] We carried some steel pipe, and ropes and some wood. So, Bosun, AB, and fitter and some of the young guys, I think at least five or six people carry some of the protective tool to, yes, to protect ourselves against these two guys, yes. Because when we heard this news actually, we didn't know how many stowaways we had on board. How many African guys, what kind of weapon they had, maybe some knife or maybe some of the more dangerous weapon. So, we use some protection too, yes. (Capt. Yang, Chinese)

When stowaways are found on board, seafarers are legally obligated to treat them in a humane manner which includes monitoring their health, providing adequate food and suitable accommodation, abstaining from any form of maltreatment, avoiding putting them to work as well as allowing them to exercise daily (IMO 2011; Jones 2014; NEPIA 2015; GARD n.d.). However, seafarers are also instructed to maintain security procedures throughout the period stowaways are on board including locking-up the stowaways, supervising their exercise, posting a crew member as a continuous security watch and segregating stowaways into smaller numbers if they are present in large numbers. These security roles, both in ports and at sea, are embraced reluctantly by seafarers who were keen to point out during interviews that they are not security professionals.

Ship masters are also advised to ensure interactions between crew members and stowaways are kept to the absolute minimum so as to inhibit the development of a sympathetic relationship which might prompt seafarers to provide unauthorised assistance to the stowaways. This could take the form of disembarking them without notifying the appropriate authorities or assisting them to escape from the ship while in port. My interviews with both seafarers and stowaways reveal instances in which seafarers, becoming sympathetic to the life stories of stowaways, helped them with covert disembarkation. The situation should be understood in the context of many jurisdictions refusing permission for stowaways to disembark, forcing ships to sail with stowaways still on board. However, while authorities are often reluctant to 
allow their disembarkation even for the purpose of repatriation at the ship owners' expense, most are quite adamant that seafarers should treat stowaways in accordance with the relevant regulations and recommended practices. For instance, one seafarer, who had very young stowaways on board for months, highlighted the contradiction in state policies and practices of checking the onboard treatment of stowaways while simultaneously refusing their disembarkation.

\begin{abstract}
These people were coming to us to interview us about, and it seems like all of them have the same checklist, about how we are treating them, what are we feeding them, and all of that. [...] And then they keep asking us the same questions which we after that realised that it was just a checklist. 'What are you doing with them? What are you feeding them?' Of course, we are feeding them the same food that we eat. 'Are you beating them or torturing them?' C'mon, why should we torture them? 'Are you locking them up?' No, we are not locking them up. [...] We roamed the world with them for four months, but no one really wanted to take them. And the same thing every port, delays, quarantine, checklists, same stupid questions, nobody's taking them until the captain was sacked from the company because of that at a later stage as we know. (Capt. Karim, Egyptian)
\end{abstract}

As the above account suggests, there are instances where stowaways can have serious implications for the jobs and careers of seafarers because ship owners can incur significant costs when stowaways are found on board. P \& I Clubs cover the direct costs associated with stowaways such as the cost of their maintenance on board, disembarkation and repatriation costs including fines by states, the cost of fuel for any diversion for the purpose of repatriation and so on. However, the costs of delays or being rendered 'off-hire' in the case of charter-parties are not covered. Hence, some ship owners can penalise seafarers as they deem them to have failed to meet their obligations. The fear produced by such actions is exacerbated due to the prevalence of temporary employment in shipping and a sense of being easily replaceable (Kahveci and Nichols 2006; Bhattacharya 2011; Xue et al. 2016).

The combined effect of the aforementioned factors can be so severe that 'solutions' resorted to by seafarers can include stowaways being forced off the ship onto makeshift rafts in the middle of the sea. Based on interviews with stowaways and seafarers as well as analysis of various documentary data, I have compiled a number of such incidents. My data indicates interesting patterns such as the provision of floating aids along with water and, at times, food in most cases (see Senu 2018, pp. 258-259). Although these actions by seafarers are certainly criminal and inhumane, it is clear that many of them make attempts to mitigate the consequences of their actions through the 'humane' supply of provisions to aid survival. This conjures up the 'humanitarianism light' (Basaran 2015, p. 213) approach alluded to earlier in the chapter that arises, in part, from the conflicting roles associated with economic, humanitarian and security obligations. 


\section{Conclusion}

Heller and Pezzani (2016, p. 14) point out that when the Italian militaryhumanitarian rescue mission Mare Nostrum was in place, 42,061 migrants were rescued by commercial shipping accounting for $25 \%$ of the total number. However, with the termination of Mare Nostrum this increased to 30\%. This surge subsequently reduced following the expansion of rescue missions by Italian authorities, the involvement of FRONTEX, EUMEDNAVFOR, an Irish governmental humanitarian mission as well as various NGOs (Cuttitta 2018, pp. 638-639). This emphasises the importance of commercial shipping in rescues, particularly when the presence of other more suited actors to undertake large-scale rescues at sea is reduced. Considering the significant numbers of migrants who perish on the Mediterranean Sea (https://missingmigrants.iom.int/region/mediterranean), the involvement of shipping in saving lives at sea is crucial.

Nonetheless, as various stakeholders in the shipping community have emphasised to governments in the EU, commercial ships and their crews are not equipped to undertake large-scale rescues (ECSA 2015). Furthermore, rescuing and dealing with migrants entails significant challenges and imposes conflicting expectations on seafarers' performance. While this is widely acknowledged by those in the shipping industry, the academic literature has lacked substantive engagement with the roles of seafarers in migration governance, save for a few exceptions. This chapter has sought to centre seafarers at the heart of the debate by attempting to flesh out the tensions that emerge from diverging economic, humanitarian and security expectations in relation to two groups of migrants. As highlighted in the chapter, such diverging expectations have serious implications for both seafarers and migrants. Acknowledging and addressing these tensions is crucial to the alleviation of the burden on seafarers, while at the same time is very likely to prevent deaths and save lives at sea.

\section{References}

Aarstad, Å.K. 2015. The Duty to Assist and Its Disincentives: The Shipping Industry and the Mediterranean Migration Crisis. Mediterranean Politics 20 (3): 413-419.

Andersson, R. 2014. Illegality, Inc.: Clandestine Migration and the Business of Bordering Europe. Oakland: University of California Press.

Bailliet, C. 2003. The "Tampa" Case and Its Impact on Burden Sharing at Sea. Human Rights Quarterly 25 (3): 741-774.

Basaran, T. 2014. Saving Lives at Sea: Security, Law and Adverse Effects. European Journal of Migration and Law 16 (3): 365-387.

. 2015. The Saved and the Drowned: Governing Indifference in the Name of Security. Security Dialogue 46 (3): 205-220.

BBC. 2000. Stowaways Hijack Ship. [Online]. Available at: http://news.bbc.co.uk/1/hi/world/ south_asia/786664.stm. Accessed 3 July 2016. 
2009. Italy acquits migrant rescue crew. [Online]. Available at: http://news.bbc.co.uk/1/hi/ 8295727.stm. Accessed 19 Jan 2014.

- 2014. Cyprus police end migrant stand-off abroad cruise ship. [Online]. Available at: http://www.bbc.co.uk/news/world-europe-29358265. Accessed 04 Dec 2017.

2017. Award for Scottish ship's captain who rescued 907 migrants. [Online]. Available at: http://www.bbc.co.uk/news/uk-scotland-tayside-central-41472873. Accessed 04 Dec 2017.

Bhattacharya, S. 2011. Sociological Factors Influencing the Practice of Incident Reporting: The Case of the Shipping Industry. Employee Relations 34 (1): 4-21.

BIMCO. 2013. The Ship Master's Security Manual: Guidance and Advice on Stowaways. Bagsværd: BIMCO Informatique A/S.

CIR. 2007. CIR Report Regarding Recent Search and Rescue Operations in the Mediterranean. [Online]. Available at: http://www.europarl.europa.eu/hearings/20070703/libe/cir_report_en. pdf. Accessed 28 June 2015.

Cooper, N. 2014. Hostage to Stowaways. Seaways (April issue): 4-5.

Coppens, J. 2013a. The Essential Role of Malta in Drafting the New Regional Agreement on Migrants at Sea in the Mediterranean Basin. Journal of Maritime Law \& Commerce 44 (1): 89-115.

- 2013b. The Lampedusa Disaster: How to Prevent Further Loss of Life at Sea? The International Journal of Marine Navigation and Safety of Sea Transportation 7 (4): 589-598.

Coppens, J., and E. Somers. 2010. Towards New Rules on Disembarkation of Persons Rescued at Sea? The International Journal of Marine and Coastal Law 25 (3): 377-403.

Cusumano, E. 2017. Emptying the Sea with a Spoon? Non-governmental Providers of Migrants Search and Rescue in the Mediterranean. Marine Policy 75 (1): 91-98.

Cuttitta, P. 2014. From the Cap Anamur to Mare Nostrum: Humanitarianism and Migration Controls at the EU's Maritime Borders. In The Common European Asylum System and Human Rights: Enhancing Protection in Times of Emergencies. CLEER Working Papers 2014/7 ed, ed. C. Matera and A. Taylor, 21-37. The Hague: T.M.C Asser Institute.

- 2018. Repoliticization Through Search and Rescue? Humanitarian NGOs and Migration Management in the Central Mediterranean. Geopolitics 23 (3): 632-660.

Davies, M. 2003. Obligations and Implications for Ships Encountering Persons in Need of Assistance at Sea. Pacific Rim Law \& Policy Journal 12 (1): 109-141.

ECSA. 2015. Humanitarian Crisis in the Mediterranean Sea. Brussels/London.

Fairplay. 2015. Captain calls for 'diplomatic' leadership and guidelines in Med rescues. [Online]. Available at: https://fairplay.ihs.com/article/17652/news-insight-master-recounts-migrant-res cue. Accessed 04 Dec 2017.

Fekete, L. 2009. Europe: Crimes of Solidarity. Race \& Class 50 (4): 83-97.

GARD. n.d. GARD Guidance on Stowaways. [Online]. Available at: http://www.gard.no/Content/ 13385148/Guidance\%20on\%20stowaways.pdf. Accessed 06 Aug 2013.

Goddard, K.S. 2015. Rescuing Refugees and Migrants at Sea: Some Commercial Shipping Implications. The Journal of International Maritime Law 21 (5): 352-367.

Grech, H. 2007. Illegal immigrants floating in limbo. TIMES OF MALTA [Online]. Available at: http://www.timesofmalta.com/articles/view/20070528/local/illegal-immigrants-floating-inlimbo.16401. Accessed 28 June 2015.

Heller, C., and L. Pezzani. 2016. Ebbing and Flowing: The EU's Shifting Practices of (Non-) Assistance and Bordering in a Time of Crisis. Near Futures [Online] 1. Available at: http:// nearfuturesonline.org/ebbing-and-flowing-the-eus-shifting-practices-ofnon-assistance-and-bor dering-in-a-time-of-crisis/. Accessed 28 Nov 2017.

Holder, A. 1997. Stowaways. In Shipping at Risk: The Rising Tide of Organised Crime, ed. E. Ellen, 230-246. Paris: ICC Publishing SA.

HRW. 2009. Pushed Back, Pushed Around: Italy's Forced Return of Boat Migrants and Asylum Seekers, Libya's Mistreatment of Migrants and Asylum Seekers. New York: Human Rights Watch. 
Huysmans, J. 2000. The European Union and the Securitization of Migration. Journal of Common Market Studies 38 (5): 751-777.

\section{Routledge.}

ICS. 2015. Large Scale Rescue Operations at Sea: Guidance on Ensuring Safety and Security of Seafarers and Resued Persons. 2nd ed. London: International Chamber of Shipping.

- 2018. Shipping Industry Increasingly Worried About EU Member States' Policy on Migrants Rescued at Sea. [Online]. Available at: http://www.ics-shipping.org/news/pressreleases/view-article/2018/06/26/shipping-industry-increasingly-worried-about-eu-memberstates-policy-on-migrants-rescued-at-sea. Accessed 29 Dec 2018.

IMO. 2011. Revised Guidelines on the Prevention of Access by Stowaways and the Allocation of Responsibilities to Seek the Successful Resolution of Stowaway Cases. Resolution FAL.11 (37) adopted on 9 September 2011.

IMO., et al. 2015. Rescue at Sea: A Guide to Principles and Practices as Applied to Refugees and Migrants.

Jarvis, R.M. 1988. Rusting in Drydock: Stowaways, Shipowners and the Administrative Penalty Provision of INA Section 273 (d). Tulane Maritime Law Journal 13 (1): 25-49.

Jones, S. 2014. Stowaways by Sea: Maritime Security Handbook. London: The Nautical Institute.

Kahveci, E., and T. Nichols. 2006. The Other Car Workers: Work, Organisation and Technology in the Maritime Car Carrier Industry. Basingstoke: Palgrave Macmillan.

Kellett, J., et al. 2015. Best Management Practices for Large Scale Rescue Operations at Sea. In InterManger Large Scale Rescue At Sea Workshop. Brussels: Allmode Limited.

Kenney, F.J., Jr., and V. Tasikas. 2003. Tampa Incident: IMO Perspectives and Responses on the Treatment of Persons Rescued at Sea. Pacific Rim Law \& Policy Journal 12 (1): 143-178.

Kilpatrick, R.L. 2017. The 'Refugee Clause': Why Contractual Allocation of Rescue Costs is Critical During Periods of Mass Migration at Sea. NUS Centre for Maritime Law Working Paper. Singapore: National University of Singapore.

Kilpatrick, R.L., and A. Smith. 2015. The International Legal Obligation to Rescue During Mass Migration at Sea: Navigating the Sovereign and Commercial Dimensions of a Mediterranean Crisis. U.S.F Maritime Law Journal 28 (2): 141-194.

Maccanico, Y. 2006. EU/Africa: Carnage continues as EU border moves south. Statewatch Immigration Analysis [Online] (55). Available at: http://www.statewatch.org/news/2006/sep/ Immigration-analysis.pdf. Accessed 18 Jan 2014.

— 2012. Securitising Maritime Transport: Shipping Merchandise and Dealing with Stowaways. Statewatch Journal 22 (1): 9-13.

MaltaToday. 2013. Salamis heads to Italy as Malta refuses access to rescued asylum seekers. [Online]. Available at: http://www.maltatoday.com.mt/news/national/28928/slideshowsalamis-adrift-malta-refuses-access-to-rescued-asylum-seekers-20130806\#.WiTEJmdLE5v. Accessed 02 Dec 2017.

Maquet, P., and J.B. Zortea. 2013. Sanctions for Stowaways: How Merchant Shipping Joined the Border Police. Statewatch Journal 23 (2): 38-42.

Mason, M. 1987. Alien Stowaways, The Immigration and Naturalization Service, and Shipowners. Tulane Maritime Law Journal 12 (2): 361-371.

McConnell, M. 1997. "Forward This Cargo to Taiwan": Canadian Extradition Law and Practice Relating to Crime on the High Seas. Criminal Law Forum 8 (2): 335-351.

Miglierini, J. 2016. Migrant tragedy: Anatomy of a shipwreck. BBC News [Online]. Available at: http://www.bbc.co.uk/news/world-europe-36278529. Accessed 03 Dec 2017.

Miller, M.S. 2009. The Stowaway Problem: Revisiting the 2002 Amendments to the FALL Convention. Currents 29: 4-7.

NEPIA. 2001. Stowaways: An Increasing Problem. Signals Special Edition (6).

2015. Stowaways. Loss Prevention Briefing [Online]. Available at: http://www.nepia.com/ media/278327/LP-Briefing-Stowaways-July-2015.PDF. Accessed 18 Feb 2015. 
Nourse, D.A. 1993. Detention of Stowaways: Who Should Bear the Cost? USF Maritime Law Journal 6 (2): 435-448.

Ort, B.A. 1991. International and US Obligations Toward Stowaway Asylum Seekers. University of Pennsylvania Law Review 140 (1): 285-366.

Papadopoulos, D., and V.S. Tsianos. 2013. After Citizenship: Autonomy of Migration, Organisational Ontology and Mobile Commons. Citizenship Studies 17 (2): 178-196.

Parrit, B.A.H., and C.J. Parker. 1992. The Answer: A Practical Response to the Stowaway Problem. In Stowaways by Sea: Illegal Immigrants-Refugees-Asylum Seekers: A Nautical Institute Practical Guide to a Growing International Problem, ed. B.A.H. Parrit, 115-120. London: The Nautical Institute.

Robertson, B. 1997. Preventative Security. In The Mariner and the Maritime Law: Seminar 8 Stowaways, 35-42. North East Branch: The Nautical Institute.

Scully, D. 2017. Chaos shits Technomar bulker as crew threatened by Nigerian stowaways. [Online]. Available at: http://splash247.com/chaos-hits-technomar-bulker-as-crew-threatenedby-nigerian-stowaways/. Accessed 03 Dec 2017.

Senu, A. 2018. The Global Assemblage of Multi-Centred Stowaway Governance. Unpublished $\mathrm{PhD}$ Thesis, Cardiff University.

Statewatch. 2007. Criminalising solidarity- Cap Anamur trial underway. Statewatch News Online [Online]. Available at: http://www.statewatch.org/news/2007/apr/03italy-cape-anamur.htm. Accessed 17 Jan 2014.

Steglich, E. 1999. Hiding in the Hulls: Attacking the Practice of High Seas Murder of Stowaways Through Expanded Criminal Jurisdiction. Texas Law Review 78 (6): 1323-1346.

Strik, T. 2012. Lives Lost in the Mediterranean Sea: Who Is Responsible? Strasbourg: Committee on Migration, Refugees and Displaced Persons, Council of Europe.

Tauman, J.E. 2002. Rescued at Sea, But Nowhere to Go: The Cloudy Legal Waters of the Tampa Crisis. Pacific Rim Law \& Policy Journal 11 (2): 461-496.

The Telegraph. 2009. Italy to allow disputed migrant ship to dock. [Online]. Available at: http:// www.telegraph.co.uk/news/worldnews/europe/italy/5184979/Italy-to-allow-disputed-migrantship-to-dock.html. Accessed 02 Dec 2017.

Valverde, M. 2014. Studying the Governance of Crime and Security: Space, Time and Jurisdiction. Criminology and Criminal Justice 14 (4): 379-391.

WatchTheMed. 2013. Tanker 'Salamis' carrying migrants stopped from entering Malta. [Online]. Available at: http://watchthemed.net/reports/view/18. Accessed 03 Dec 2017.

Williams, J.M. 2016. The Safety/Security Nexus and the Humanitarianisation of Border Enforcement. The Geographic Journal 182 (1): 27-37.

Xue, C., et al. 2016. Who is Dominant? Occupational Health and Safety management in Chinese Shipping. Journal of Industrial Relations 59 (1): 65-84.

Open Access This chapter is licensed under the terms of the Creative Commons Attribution 4.0 International License (http://creativecommons.org/licenses/by/4.0/), which permits use, sharing, adaptation, distribution and reproduction in any medium or format, as long as you give appropriate credit to the original author(s) and the source, provide a link to the Creative Commons licence and indicate if changes were made.

The images or other third party material in this chapter are included in the chapter's Creative Commons licence, unless indicated otherwise in a credit line to the material. If material is not included in the chapter's Creative Commons licence and your intended use is not permitted by statutory regulation or exceeds the permitted use, you will need to obtain permission directly from the copyright holder.

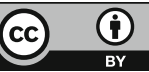

